\title{
Science and Technology Networks in the Canadian Forest Service
}

\author{
by J. Peter Hall ${ }^{1}$
}

The Canadian Forest Service has reorganized its science and technology programs to focus on establishing partnerships and networks, thereby becoming a partner to business, academic institutions, other governments and voluntary organizations to stimulate increased S\&T activity. Current policy issues in the forest sector reflect the changing nature of our society and the demands on forests in particular.

The CFS has established national networks in the following fields: Effects of Forest Practices, Landscape Management, Climate Change, Fire Management, Socio-Economic Research, Pest Management Methods, Ecosystem Processes, Tree Biotechnology and Advanced Genetics, Biodiversity, and Forest Health.

This national network-based approach to deliver its S\&T program will allow us to address national and international issues while delivering programs through regional research centres. As the Canadian forest sector competes in world markets, it will have to meet international demands for sustainable forest management.

Key words: networks, partnerships, alliances, forest issues
Le Service canadien des forêts a remanié ses programmes scientifiques et technologiques pour les centrer sur la mise en place de partenariats et de réseaux, devenant ainsi un partenaire pour le monde des affaires, les institutions académiques, les autres gouvernements et les organismes bénévoles pouvant stimuler un accroissement de l'activité en sciences et technologies.Les enjeux politiques actuels du secteur forestier sont le reflet de la nature changeante de notre société et des demandes orientées vers les forêts en particulier.

Le SCF a mis en place des réseaux nationaux dans les domaines suivant: incidences des pratiques forestières, l'aménagement des paysages, changement climatique, recherche socio-économique, méthodes de lutte contre les ravageurs, processus des écosystèmes forestiers, biotechnologie des arbres et génétique de pointe, biodiversité des forêts, et santé des forêts.

Cette approche en fonction de réseaux nationaux d'application des sciences et technologies nous permettra de répondre aux questions nationales et internationales tout en mettant en place des programmes par l'entremise des centres régionaux de recherche. Alors que le secteur forestier canadien est en compétition sur les marchés mondiaux, il pourra répondre aux demandes internationales d'aménagement forestier durable.

Mots clés: réseaux, partenariat, alliances, enjeux forestiers

\section{Introduction}

The Canadian Forest Service (CFS) is reorganizing its science and technology (S \& T) programs to better reflect the changing circumstances and needs of the forest sector.

Increasingly, the access of the forest sector to international markets depends on its ability to demonstrate sustainable forest management practices. In addition, forests are attracting public attention as a result of the increased international attention on environmental issues.

A substantial part of the agenda for forests is embodied in national and international commitments such as the UN Commission on Sustainable Development, the Intergovernmental Panel on Forests, Canada's National Forest Strategy and the Canada Forest Accord, as well as the national and international Criteria and Indicators initiatives. Canadian initiatives such as the Model Forest Program have been established to further implement and demonstrate sustainable forest management practices.

As a result of the 1995 Federal Program Review, the CFS, along with the other federal R\&D agencies, substantially refocused and restructured its activities. As "Science and Technology for the New Century: A Federal Strategy" points out:

With smaller budgets, it is now more important that ever to invest our resources strategically, so that Canadians can obtain the maximum economic, social and scientific returns. This means both focussing on core activities and finding more efficient and effective ways to deliver them.

${ }^{1}$ Natural Resources Canada, Canadian Forest Service, 580 Booth Street, Ottawa, Ontario, Canada K1A 0E4.
The federal government recognizes that if Canada is to maintain its leading edge in worldwide forest management technology and forest product markets, the forest sector must create a climate conducive to research and innovation. Yet resources available for forestry research in Canada simply do not allow the federal government or any other single agency to address all priorities. Research partnerships and alliances between government and outside agencies are key to meeting the needs of the forest sector.

The CFS strategy is to focus on establishing partnerships and networks, thereby shifting its role to that of a partner to business, academic institutions, other governments and voluntary organizations to stimulate increased S\&T activity.

The CFS aims to maintain and enhance its work with its industry client partners to find innovative and sustainable forest management techniques and to provide information needed to reach international agreement on criteria for sustainable forest management. These are crucial to the future competitiveness and market acceptability of Canada's forest products. This paper outlines the policy issues, network structure, and the function of networks.

\section{Forest Policy Issues}

Current policy issues reflect the changing nature of our society and the many demands placed on natural resources generally, and on forests in particular. Forests are expected to provide economic returns for a large part of our society, particularly in rural areas where forests are often the main economic base for employment and sustainability. In urban areas, forests provide other values: recreation and spiritual renewal. 
If forests are to be managed sustainably, we need to know the answers to such questions as, can forest management mimic natural forest succession through our reforestation policies? Do we have the information to determine what forest practices will allow us to manage forests in a way that is environmentally acceptable, economically feasible and socially responsible? Do we know what processes keep forest ecosystems productive and how natural disturbances and human activities affect these processes?

Of particular need is an assessment of the values at risk from wildland fire and a determination of the appropriate levels of fire management. Losses of and damages to commercial timber and non-commercial forests as a result of insects, diseases and fire need to be reduced to economically acceptable levels without unacceptable environmental impacts, or once again sustainability will be impaired. In our forest-based communities, the social and economic indicators of sustainable forest management are of great importance, yet we do not know how they can be measured and integrated into decisionmaking locally, nationally and internationally.

Interest is high in the conservation and preservation of forests and therefore we need to be aware of the status of biodiversity in our forests, and what constitutes effective conservation of forest biodiversity. This information, on a larger scale, impacts on landscapes, ecosystems, species and genes.

Changes in our environment affect us all wherever we live, and forests are no exception. Forests have been affected in the past and will be impacted in the future by such environmental stresses as air pollution and climate change. Do we know the status of the health of Canada's forest ecosystems? Is it changing? How will climate change affect our forests and what will be the economic, social and environmental consequences of these changes? These issues will determine how we manage our forests, our quality of management will reflect the quality of information we use to manage.

\section{Partnerships and Alliances}

As many research organizations know only too well, good research needs more than good science. Much more is expected from public and private research and development investment portfolios. In addition, shrinking budgets are making us ever more reliant on strategic alliances and partnerships. The CFS is in a position to form partnerships and alliances with outside agencies to create and sustain dynamic, mutually beneficial relationships. Partnerships will include internal collaborations in the CFS (between networks) or external alliances (between networks and other partners.)

Collaboration between CFS networks and outside agencies can be either partnerships or alliances. Under partnerships, both agencies contribute resources to support a specific project or issue. The outside agency may receive certain agreed upon deliverables from the project or the network as a whole.

An alliance between the CFS and an outside agency, involves collaboration formally or informally, but not shared resources. Both agencies work toward common goals by undertaking research studies and/or sharing information.

Successful alliances or partnerships between CFS S\&T Networks and other agencies will respect the need for each partner to achieve strategic goals, while creating a dynamic, mutually beneficial relationship, and allow partner agencies to fulfil their own mandates and contribute to a greater effort to benefit the sector and nation. The partnerships/alliances will add value by providing skills and resources that promote progress, and produce results that exceed the sum of what the individual agencies could achieve singly.

As a national agency, the CFS can ensure that the forest community across the country is aware of current information and new or emerging technologies. The opportunities for partnerships with the CFS will mean access to research results and technologies, greater involvement in priority setting, and greater input in developing science to address sector needs.

\section{Network Structure}

The CFS S \& T Networks have been developed around strategic policy issues and research priorities at regional, national and international levels, according to the mandate, resources, facilities and expertise of the CFS. To ensure that the S\&T Network activities are relevant to the forest sector, the programs will not only build on a series of scientific partnerships and alliances, they will also focus on the transfer of technology to resource managers and other clients, links between corporate policy and sector policy, and international agreements and commitments. The S\&T Networks will eventually encompass most of the CFS's science program activities. The purpose of the S\&T program is to give forest stakeholders the tools to perfect sustainable forest management.

Each national S\&T Network will be led by one of the five CFS centres in Victoria, British Columbia; Edmonton, Alberta; Sault Ste. Marie, Ontario; Sainte-Foy, Quebec; and Fredericton, New Brunswick. The networks are national and international in scope, strategic in their approach to forest science and policy issues, and managed so that their outputs exceed the sum of their parts. Most establishments have scientists in all Networks, enabling CFS partners and alliances to access a national S\&T Network from any CFS centre in Canada.

The CFS S\&T Networks are developed around:

- Developing technologies to integrate information and to support decision-making,

- Maintaining and enhancing forest ecosystem health, productivity, competitiveness and preserving market access in the forest sector.

Almost all elements of the program affect sustainable forest management and, directly or indirectly, affect access to global markets, wealth and job creation, and the protection and maintenance of environmental quality. Some elements (e.g. fire management and biological control) also affect public health and safety.

\section{The Ten CFS S \& T Networks Address National Forest Issues}

\section{Effects of Forest Practices}

By developing scientifically sound forest management techniques and methods of sharing this information, we can assure our citizens and customers that the best possible forest practices are being used. Forest issues and problems are not constrained by artificial boundaries between provinces and landowners so co-operation between governments and other forest managers is imperative. Also, practices that function well in one part of Canada may not work in another. The Network will examine current and alternative silvicultural practices, and 
test them in various parts of Canada. As techniques are proven to be environmentally and economically sound, technologies that represent the best forest practices will be transferred to forest managers.

\section{Landscape Management}

To achieve forest sustainability we need a better understanding of how the environment, human activities and natural disturbances interact to shape the forest landscape. The Network will work with its partners and allies to measure the success of our forest management activities using key indicators. Success in this area will lead to success in demonstrating these accomplishments to our international trading partners.

The Network will include partners managing large forest landscapes and who use decision support systems, and who are committed to working toward sustainable forestry. Provincial governments, with primary responsibility for forest management maintain significant inventory and other database information critical to the network's efforts, and strong linkages to them and other CFS networks are necessary.

\section{Climate Change}

There is a consensus among scientists that the increasing concentration of atmospheric carbon dioxide resulting from human activity is having a discernible effect on the climate. Forests may be adversely affected, but they also can contribute to enhancing and sustaining carbon sinks and reservoirs. A variety of forest management options are available to address the potential effects of climate change. A better understanding of the carbon cycle is important because it is the link between forests and the climate system. Climate change is a global problem that has prompted studies on a wide range of social, economic and environmental issues. Increased understanding of these global cycles will enable us to adapt to climate change while allowing us to remain leaders in the science of the issue.

\section{Fire Management}

Wildland fire management represents $25 \%$ of the cost of forest management in Canada, and fire threatens the destruction of forest communities, consumes nearly as much wood as we harvest, and is the dominant ecological disturbance in much of our forests. At the same time, exclusion of fire is not generally physically possible, economically feasible, or ecologically desirable. Fire management policies are based on the supposition that suppression should be proportional to values at risk and that the natural role of fire in managing the landscape should be recognized. Improvement of fire management requires more knowledge about fire as a physical, biological and socio-economic phenomenon, coupled with much more sophisticated decision-making and tools.

The CFS fire research program has a long history of partnerships with other government departments and universities, nationally and internationally. The CFS will seek participation from universities and other research organizations interested in addressing key fire management issues, and will conduct research on fire environment, ecology and fire management systems.

\section{Socio-Economic Research}

Forest management issues have expanded from concerns about timber supply to include other forest values. Decisions now involve participation by government, industry and community interest groups; consequently forest management must take into account issues from local to the international scale. More information is needed on how forestry practices affect the health of rural and aboriginal resource-based communities. Enhanced methods are needed to assess the social and economic implications of sustainable forestry.

The Socio-Economic Research Network is closely linked to universities, and projects are underway with Model Forests, which serve as operational models of integrated resource management. The involvement of National Parks in the Model Forests is another opportunity to expand partnerships.

The Network has created partnerships and linkages with many institutions in the U.S. and abroad. Their expertise will be valuable in developing new methodologies and knowledge in critical areas in the measurement of sustainability, and the creation of a framework for assessing issues affecting the forest sector.

\section{Pest Management}

The protection of Canada's forest resource against damaging insects, disease-causing organisms and competing vegetation is one strategy to promote sustainable development. Methods to protect the resource must be effective without impacting negatively on public health or ecological integrity.

The CFS has long played a leading role in developing cost-efficient approaches to pest management research by building on research partnerships and strategic alliances. Our partners have included the pest control industry, forest companies, provinces, universities, and other national and international agencies and collaborators. The Network will continue to maintain programs in development of environmentally benign pesticides, biological control of forest pests and the integrated management of pests.

\section{Ecosystem Processes}

Recent developments and advances by the forest sector have identified considerable gaps in the ecological knowledge base needed for sustainable forest management. This reflects the vastness and diversity of our forests and the inherent complexity of forest ecosystems. At the same time we require the ability to predict the results of management decisions and natural disturbances.

The Network, in collaboration with industry, provinces and universities, will conduct and coordinate a program of ecological research in the forested ecozones. The Network will focus on developing criteria and measurements for sustainable resource utilization and increasing our ability to forecast how disturbances affect the forest landscape.

The Network will build strong partnerships with public and private sector users, increase predictive capabilities and help address issues of forest sustainability.

\section{Tree Biotechnology and Advanced Genetics}

The sustainability of our forests and the maintenance of our markets for wood products are dependent on our ability to improve productivity of our forests, and protect and conserve our forests at the same time. One of the keys to increasing forest productivity is using tree biotechnology and advanced genetics to produce trees with enhanced growth rates, pest tolerance and wood quality. Tree biotechnology can provide the tools 
to accelerate the breeding cycle and to provide environmentally acceptable solutions to problems where alternatives are unavailable.

Partnerships are a proven way to demonstrate the feasibility of CFS-developed biotechnologies to forest managers. The Network will strengthen and develop partnerships with the private sector for the application of biotechnologies and advanced genetics. The network will build on current successful collaborations with universities and research organizations outside Canada, particularly in Sweden, France, New Zealand and the United States.

\section{Biodiversity}

Canadians increasingly recognize that the future sustainability of the forest resource depends on maintaining the adaptive capacity, ecological stability and biological diversity of forests. The increased awareness is the result of national and international concerns about the potential loss of biodiversity due to human activity and natural disturbances. The challenge is to recognize biodiversity as a cornerstone of sustainable development, thereby maintaining the importance of the forest sector. To meet this challenge, Canada has ratified the International Convention on Biological Diversity and developed a Canadian Biodiversity Strategy.

The Network is attempting to develop working definitions of forest biodiversity, and to monitor the state of biodiversity. Biodiversity is addressed at the ecosystem, species and genetic levels. Conservation of biodiversity is prominently featured in the development of the domestic and international Criteria and Indicators of sustainable forest management. The Network will establish and strengthen linkages and partnerships with other federal and provincial authorities, the forest industry, industry associations, academia, and non-government organizations nationally and internationally. These links and partnerships will make it possible to address issues related to biodiversity.

\section{Forest Health}

The CFS is being called upon to make predictions about the health of Canada's forests, particularly the effects of acid deposition and air pollution on forest vegetation and the impacts of control of acid rain-related pollutants. Monitoring and research are necessary to assess and report on the health condition of the forests; to predict and monitor changes related to ecosystem and species diversity, disturbance and stress, occurrence of exotic pests, and to develop indicators for sustainable forest management.

A national health monitoring system using assessment-based information can evaluate forest condition. The Network is a cornerstone of Canada's international commitment to sustainable forestry and provides valuable assistance in support of our international trade. The Network vision of a healthy forest is shared by other research and ecological monitoring networks in Canada and abroad. By linking and coordinating our monitoring and research programs, we can increase our understanding of the factors affecting forest health.

\section{Conclusions}

More knowledge is needed on ecosystem processes, the health and diversity of our forests, non-timber uses, and ways to increase the productivity and value of forests. This knowledge will enable forest managers to achieve our goal of sustainable forest management. The S\&T program addresses the more strategic or fundamental national and international issues faced by the forest community.

The CFS has adopted a national network-based approach to deliver its S\&T program. The Networks will allow us to address national and international issues while delivering programs through regional research centres. The Networks are well suited to create partnerships and alliances between the CFS and outside agencies, to undertake research that addresses national issues.

In summary, as the Canadian forest sector competes in world markets, it will meet international demands for sustainable forest management. More research will be needed to meet these demands, a need that cannot be met by government or outside agencies alone. By collaborating on joint projects and strategic decisions, the CFS and other agencies can maximize the use of resources, enhance their research efforts and maintain Canada's reputation as a world leader in sustainable forest management.

\section{References}

Anon. 1996. Science and technology networks - 1996 consultations. Can. For. Ser., Nat. Res. Can., Ottawa, 18p.

Anon. 1996. Science and technology for the new century: A federal strategy, Govt. of Can. 38 pages. Ottawa.

Anon. 1996. The science and technology management network, Natural Resources Canada, Ottawa. 9 p. 